Clinical Endocrinology (1981) 15, 139-149

\title{
EFFECTS OF CIMETIDINE ON PITUITARY FUNCTION: ALTERATIONS IN HORMONE SECRETION PROFILES
}

\author{
T. W. VALK, B. G. ENGLAND AND J. C. MARSHALL \\ Department of Internal Medicine, Division of Endocrinology and Metabolism and the \\ Metabolism Research Unit, and the Department of Pathology, University of Michigan, \\ Ann Arbor, Michigan, USA
}

(Received 24 September 1980; revised 16 February 1981; accepted 25 February 1981)

\begin{abstract}
SUMMARY
Cimetidine, an $\mathrm{H}_{2}$ receptor antagonist, was given for 6 weeks to six normal male volunteers to study the effects on pituitary, adrenal, thyroid, and testicular hormone secretion. Patients were studied before (day 1) and after (day 42) cimetidine ( $300 \mathrm{mg}$ four times daily) therapy, and four of the six were restudied after discontinuing cimetidine for 1 month (day 72). Basal TSH concentrations and responses to TRH administration as well as T3 RIA and T4 resin uptakes did not change during or after cimetidine therapy. The diurnal rhythm of plasma cortisol and maximum cortisol response to insulin $(0.15 \mathrm{u} / \mathrm{kg})$ were similar on days 1 and 42 , but urinary free cortisol excretion fell $31 \%(P<0.01)$. Response of $\mathrm{GH}$ to exercise, $100 \mathrm{~g}$ carbohydrate ingestion and insulin were unchanged, but mean nocturnal GH secretion decreased $33 \%(P<0.025)$ on cimetidine, and returned to baseline on day 72 . The $24-\mathrm{h}$ plasma prolactin profile was unchanged as was the prolactin response to insulin and TRH stimulation. Plasma FSH was not altered, but mean LH concentrations decreased $20 \%$ on cimetidine and continued to decline ( $45 \%$ of day 1 levels) after discontinuation of cimetidine $(P<0 \cdot 01)$. Spontaneous LH pulse amplitude declined slightly on day 42 , but became significantly lower on day $72(P<0.01)$ while pulse frequency increased modestly on day $72(P<0.05)$. Peak LH responses to gonadotropin-releasing hormone were also reduced on cimetidine therapy $(P<0 \cdot 02)$. Plasma testosterone concentrations did not change but plasma oestradiol concentrations were $38 \%$ lower $(P<0.025)$ after cimetidine was discontinued.

$\mathrm{H}_{2}$ histamine receptors are involved in the control of multiple hormone secretory patterns and blockade of these receptors by cimetidine alters hormone profiles. These changed patterns have to be considered in the interpretation of hormone measurements in patients receiving cimetidine therapy.
\end{abstract}

Correspondence: J. C. Marshall, R3044 Kresge Research II, University Hospital, Ann Arbor, Michigan 48109, USA.

0300-0664/81/0800-0139\$02.00 (C) 1981 Blackwell Scientific Publications 
Cimetidine is a $\mathrm{H}_{2}$ histamine receptor antagonist with a wide range of uses in states of gastric hyperacidity (Henn et al., 1975; Winship, 1978). Gynaecomastia (Hall, 1976; Dellefave et al., 1977) and impotence (Wolfe, 1979) have been reported in men on chronic cimetidine therapy, but the mechanisms involved in their development are unknown. Hyperprolactinaemia, both after oral (Dellfave et al., 1977; Bonnet et al., 1978) and intravenous (Delitala et al., 1978; Daubresse et al., 1979; Carlson \& Ippoliti, 1977) use has been implicated in these states. However, the hyperprolactinaemia appears to be transient after intravenous use and oral cimetidine induced hyperprolactinemia has not been confirmed (Hall, 1976; Carlson \& Ippoliti, 1977; LaBrooy et al., 1978). Furthermore, changes in plasma testosterone as well as altered $\mathrm{LH}$ responsiveness to gonadotrophin releasing hormone (GnRH) (Van Thiel et al., 1979) and elevated plasma FSH concentrations (White et al., 1979) have been described. These changes have been suggested as mechanisms whereby cimetidine could alter pituitary-gonadal function but the effects have not been reproducible (Delitala et al., 1979; Valk et al., 1979). In many of the previous studies, single estimates of hormones were made and effects of $\mathrm{H}_{2}$ receptor antagonists on the biological rhythms involved in hormonal secretion have not been fully evaluated. The effects of cimetidine on the nocturnal secretion of prolactin and growth hormone, the early morning rise in cortisol secretion, and the intermittent pulsatile release of LH and FSH have not been investigated. As hormonal rhythms may be altered before abnormalities of daytime basal plasma concentrations (Weitzman et al., 1975), study of circadian rhythms may show altered hormonal secretory patterns. This study was performed to investigate the effect of cimetidine, administered in a manner which approximates to its common use in the treatment of peptic ulcer disease, on the biological rhythms of endocrine secretion and thereby determine the effects of $\mathrm{H}_{2}$ histamine receptor blockade.

\section{METHODS}

\section{Study protocol}

Six normal male volunteers, aged 26-35 years, were investigated on a 6-week protocol. None were taking other medications during the study period. They were admitted to the Clinical Research Center on day 1 at $0730 \mathrm{~h}$, and informed consent obtained after detailed explanation of the protocol. An intravenous heparin lock was placed in the forearm and at $0800 \mathrm{~h}$ a venous sample drawn for full blood count, biochemical profile, T4 by radioimmunoassay (T4 RIA), T3 resin uptake, and a 24-h urine collection for creatinine and free cortisol was begun. Blood for $\mathrm{GH}$ assay was drawn 60,30 , and $0 \mathrm{~min}$ before, and at 20-min intervals after a $100 \mathrm{~g}$ carbohydrate meal. Venous samples were taken every 20 min from 1300 to $1700 \mathrm{~h}$ for GH, prolactin, $\mathrm{LH}$ and FSH. At $2000 \mathrm{~h}$ each volunteer was exercised to $80^{\circ}$ of calculated maximum heart rate (Fortuin \& Weiss, 1977) on a stationary bicycle for $15 \mathrm{~min}$ with measurement of $\mathrm{GH}$ before and after. At $2300 \mathrm{~h}$ the volunteers began fasting and were placed in a room at rest. At $2330 \mathrm{~h}$ the lights were turned out and the volunteers allowed to sleep. Samples from the forearm catheter were taken every $20 \mathrm{~min}$ from 2400 to $0400 \mathrm{~h}$ in a manner designed for minimal patient disturbance. Prolactin, GH, FSH, and LH were determined on each sample, and cortisol on the $2400 \mathrm{~h}$ sample. At $0800 \mathrm{~h}$ the following morning, after completion of the urine collection, a combined pituitary reserve test (Harsoulis et al., 1973) was performed. Soluble insulin $(0 \cdot 15 \mathrm{u} / \mathrm{kg})$. TRH $(200 \mu \mathrm{g})$, and GnRH $(100 \mu \mathrm{g})$ were given by i.v. bolus at 
$0830 \mathrm{~h}$ and samples for $\mathrm{GH}$, prolactin, TSH, LH, FSH, cortisol, and glucose were obtained at $0,30,45,60$, and $90 \mathrm{~min}$ after injection. The volunteers were then discharged on oral cimetidine at a dose of $300 \mathrm{mg}$ every $6 \mathrm{~h}$ for 42 days. On days 21 and 42, plasma cimetidine levels were drawn to assess compliance with the drug regimen. All volunteers were readmitted on day 42 (still taking cimetidine) and the day 1 protocol repeated. Cimetidine was discontinued after day 42 and four of the men were readmitted 30 days later for repeat studies. On day 72 the protocol was the same as day 1, except that plasma cortisol and FSH were not measured and the urinary collection and pituitary reserve test omitted. Plasma testosterone and oestradiol were determined at 1200 and $2400 \mathrm{~h}$ on each day of study.

\section{Assays}

Radioimmunoassays for GH, LH, FSH, prolactin, TSH, cortisol, testosterone and oestradiol were performed as previously described (Schalch \& Parker, 1964; Midgley, 1966; Midgley, 1967; Sinha et al., 1973; Payne et al., 1977; England et al., 1974; Pekary et al., 1977; Dash et al., 1975). Gonadotrophin results are expressed as miu of the second IRP of HMG (normal adult male range of 5-30 miu/ml). Urinary free cortisol (UFC) was measured using the modified method of Dash et al. (1975) with cortisol binding globulin heat inactivated at $90^{\circ} \mathrm{C}$ for $10 \mathrm{~min}$ to eliminate solvent extraction. Normal adult levels of urinary free cortisol range between $30-150 \mu \mathrm{g} / 24 \mathrm{~h}$, and cimetidine $(10 \mu \mathrm{g} / \mathrm{ml})$ did not interfere with the assay.

All samples for testosterone, oestradiol and UFC were performed in single assays. For the other hormones, samples on days 1 and 42 were measured in a single assay and day 72 samples in a separate assay. The interassay coefficient of variation (CV) for the GH assay was $13 \%$ and for LH the intra and interassay CVs were similar at $12 \cdot 5,10 \cdot 9$, and $8.9 \%$ for values of 5-10,10-20, and $20-30 \mathrm{miu} / \mathrm{ml}$ respectively. Plasma cimetidine was determined by high pressure liquid chromatography with therapeutic concentrations ranging from 0.5 to $2.0 \mu \mathrm{g} / \mathrm{ml}$ during oral therapy (Griffiths et al., 1977).

\section{Statistics}

Mean nocturnal growth hormone and prolactin were calculated using all samples between 2400 and $0400 \mathrm{~h}$ and an analysis of variance was performed using individual timed samples on each day of study. Mean nocturnal peak GH and prolactin were the maximum levels achieved between 2400 and $0400 \mathrm{~h}$. Mean day-time prolactin concentrations were calculated from the 1300-1700 h samples and mean LH and FSH from all the 1300-1700 and 2400-0400 h values. LH pulse frequency and amplitude were calculated using a $20 \%$ or greater increment from nadir to peak over $40 \mathrm{~min}$ as the definition of a spontaneous LH pulse (Santen \& Bardin, 1973). All other analyses were done using paired Student's $t$ tests and and all results are expressed as mean and standard error of the mean.

\section{RESULTS}

\section{Plasma cimetidine concentrations}

All six men had therapeutic plasma levels of cimetidine on days 21 and 42 . Concentrations ranged from 0.7 to $1.5 \mu \mathrm{g} / \mathrm{ml}$ on samples taken $2-6 \mathrm{~h}$ after the previous dose of cimetidine. 
Table 1. Basal and peak plasma hormone and glucose concentrations in response to combined pituitary reserve testing before (day l) and during (day 42) cimetidine administration

\begin{tabular}{|c|c|c|c|c|}
\hline & \multicolumn{2}{|c|}{ Day I } & \multicolumn{2}{|c|}{ Day 42} \\
\hline & Basal & Peak & Basal & Peak \\
\hline Cortisol $(\mu \mathrm{g} / \mathrm{dl})$ & $19 \cdot 5 \pm 0.6 \dagger$ & $21 \cdot 1 \pm 1.6 t$ & $17 \cdot 8 \pm 1 \cdot 3 \dagger$ & $21 \cdot 3 \pm 1 \cdot 1 \dagger$ \\
\hline $\mathrm{TSH}(\mu \mathrm{u} / \mathrm{ml})$ & $2 \cdot 2 \pm 0.4$ & $9 \cdot 9 \pm 1 \cdot 2$ & $2 \cdot 3 \pm 0 \cdot 4$ & $10 \cdot 6 \pm 1 \cdot 8$ \\
\hline $\mathrm{LH}$ (miu $\mathrm{ml}$ ) & $10 \cdot 4 \pm 6 \cdot 0$ & $72 \cdot 8 \pm 18 \cdot 0^{*}$ & $11 \cdot 2 \pm 3 \cdot 6$ & $63.6 \pm 12 \cdot 0^{*}$ \\
\hline FSH (miu/ml) & $2 \cdot 9 \pm 0.4$ & $4 \cdot 0 \pm 0.7$ & $3.2 \pm 0.5$ & $4 \cdot 4 \pm 0 \cdot 8$ \\
\hline $\mathrm{GH}(\mathrm{ng} \cdot \mathrm{ml})$ & $0.7 \pm 0.1$ & $27 \cdot 8 \pm 11 \cdot 9$ & $0.7 \pm 0.1$ & $23 \cdot 2 \pm 8 \cdot 8$ \\
\hline Prolactin (ng:ml) & $23 \cdot 3 \pm 3 \cdot 5$ & $113 \cdot 1 \pm 21 \cdot 3$ & $18 \cdot 4 \pm 4 \cdot 2$ & $116 \cdot 1 \pm 25 \cdot 8$ \\
\hline Glucose $(\mathrm{mg} / \mathrm{dl})$ & $99 \cdot 0 \pm 3 \cdot 6$ & $34 \cdot 3 \pm 3 \cdot 7$ & $103 \cdot 3 \pm 1 \cdot 8$ & $34 \cdot 8 \pm 2 \cdot 9$ \\
\hline
\end{tabular}

\section{Pituitary thyroid axis}

Plasma T4 RIA and T3 resin uptake levels were $7 \cdot 7 \pm 0.4 \mu \mathrm{g} / \mathrm{dl}$ (mean $\pm \mathrm{SEM}$ ) and $103.6 \pm 3.4 \%$ on day 1 , respectively. On day 42 , levels were unchanged being $8 \cdot 0 \pm 0.7$ $\mu \mathrm{g} / \mathrm{dl}$ and $98 \cdot 7 \pm 1 \cdot 2 \%$, respectively. TSH concentrations before and after TRH administration were similar on days 1 and 42 (Table 1 ).

\section{Pituitary-adrenal axis}

Plasma cortisol levels at $2400 \mathrm{~h}$ on days 1 and 42 were not different at $2 \cdot 8 \pm 0.5$ and $2 \cdot 7 \pm 0 \cdot 5 \mu \mathrm{g} / \mathrm{dl}$, respectively. Basal cortisol levels at $0830 \mathrm{~h}$ were similar and peak insulin hypoglycaemia-induced levels were unchanged by cimetidine therapy (Table 1).

Urinary free cortisol (UFC) excretion was significantly altered by cimetidine therapy. Free cortisol excretion per $24 \mathrm{~h}$ decreased by $45 \%(P<0.005)$ after 6 weeks of cimetidine (Table 2) and UFC expressed per gramme of creatinine excreted decreased by $36 \%$

Table 2. Urinary free cortisol excretion and creatinine clearance before (day 1) and during (day 42) cimetidine administration

\begin{tabular}{|c|c|c|}
\hline & Day 1 & Day 42 \\
\hline \multicolumn{3}{|l|}{ Urinary free cortisol $(\mu \mathrm{g})$} \\
\hline per $24 \mathrm{~h}$ & $56 \cdot 8 \pm 3 \cdot 7^{*}$ & $31 \cdot 0 \pm 3 \cdot 1 \S$ \\
\hline per g creatinine excreted & $28 \cdot 4 \pm 2 \cdot 1$ & $18 \cdot 2 \pm 1 \cdot 5_{4}^{+}$ \\
\hline per $100 \mathrm{ml}$ estimated GFR & $41 \cdot 9 \pm 5 \cdot 7$ & $28.9 \pm 3.8 \dagger$ \\
\hline Urinary creatinine $(\mathrm{g} / 24 \mathrm{~h})$ & $2 \cdot 0 \pm 0 \cdot 10$ & $1.7 \pm 0.07$ \\
\hline Serum creatinine (mg/dl) & $1.0 \pm 0.07$ & $1 \cdot 1 \pm 0 \cdot 08_{4}^{+}$ \\
\hline Creatinine clearance $(\mathrm{ml} / \mathrm{min})$ & $138 \cdot 9 \pm 8 \cdot 2$ & $107 \cdot 3 \pm 6 \cdot 0 \S$ \\
\hline
\end{tabular}

* Mean \pm SEM,$+P<0.01 .+P<0.005 . \S P<0.0025$. 
$(P<0-005)$. This was accompanied by an increased plasma creatinine and a lowered creatinine clearance. However, a $31 \%$ decrease in free cortisol excretion was still present $(P<0.01)$ when UFC was corrected for the decline in creatinine clearance (expressed as $\mu \mathrm{g}$ UFC per $100 \mathrm{ml} \mathrm{GFR}$ ).

\section{Growth hormone secretion}

Basal GH concentrations before a $100 \mathrm{~g}$ carbohydrate meal were similar $(2 \cdot 1 \pm 1.0$ and $3.0 \pm 2.5 \mathrm{ng} / \mathrm{ml}$ ) on days 1 and 42 , respectively. Plasma GH fell to the lower limit of assay sensitivity after the meals on both days 1 and 42 , and remained low $(0 \cdot 7 \pm 0.01 \mathrm{ng} / \mathrm{ml})$ for up to $3 \frac{1}{2} \mathrm{~h}$. Plasma glucose was not different on either occasion and peak levels were reached at $40 \min (143 \pm 6$ and $152 \pm 7 \mathrm{mg} / \mathrm{dl}$ on days 1 and 42$)$ and returned to baseline by $80 \mathrm{~min}$. Exercise produced a similar response in serum GH $(4 \cdot 4 \pm 2 \cdot 7$ and $3 \cdot 0 \pm 1 \cdot 7 \mathrm{ng} / \mathrm{ml}$ on days 1 and 42, respectively) and GH responses to insulin hypoglycemia were unchanged (Table 1). GH and glucose responses to the $100 \mathrm{~g}$ carbohydrate meal and exercise were unchanged on day 72 .

Table 3. Mean and peak nocturnal plasma GH concentration

\begin{tabular}{lcc}
\hline & $\begin{array}{c}\text { Mean nocturnal GH } \\
(\mathrm{ng} / \mathrm{ml})\end{array}$ & $\begin{array}{c}\text { Peak nocturnal GH } \\
(\mathrm{ng} / \mathrm{ml})\end{array}$ \\
\hline Day 1 & $5 \cdot 7 \pm 0 \cdot 8 \dagger$ & $16 \cdot 1 \pm 4 \cdot 6$ \\
Day 42 & $3 \cdot 9 \pm 0 \cdot 5 *$ & $12 \cdot 2 \pm 2 \cdot 9$ \\
Day 72 & $5 \cdot 5 \pm 0 \cdot 8$ & $16 \cdot 8 \pm 4 \cdot 8$ \\
\hline \multicolumn{3}{c}{$* P<0 \cdot 025}$. \\
& $\uparrow$ Mean \pm SEM.
\end{tabular}
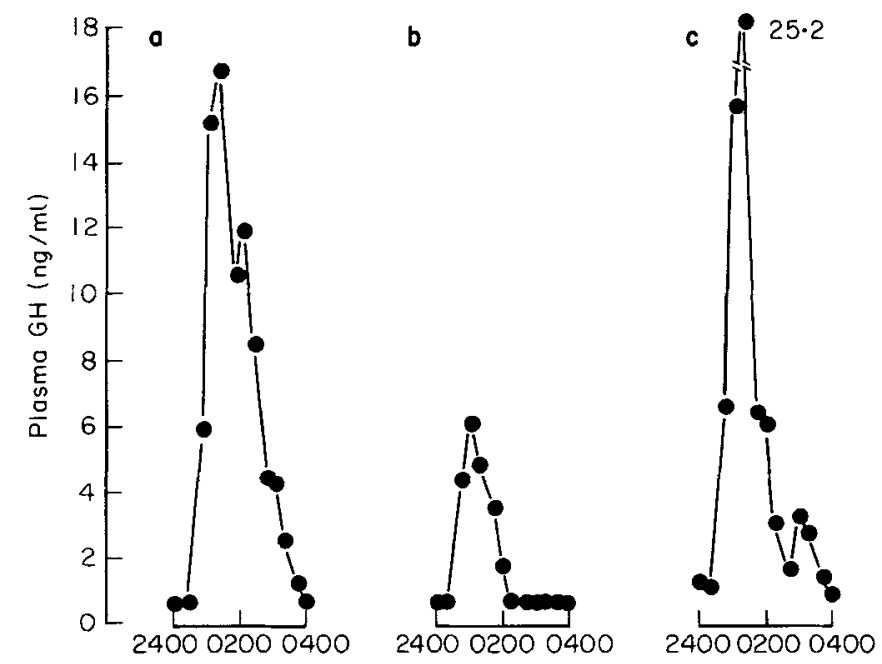

Fig. 1. Nocturnal GH concentrations in an individual before (a, day 1), during (b, day 42), and after (c, day 72) cimetidine therapy 


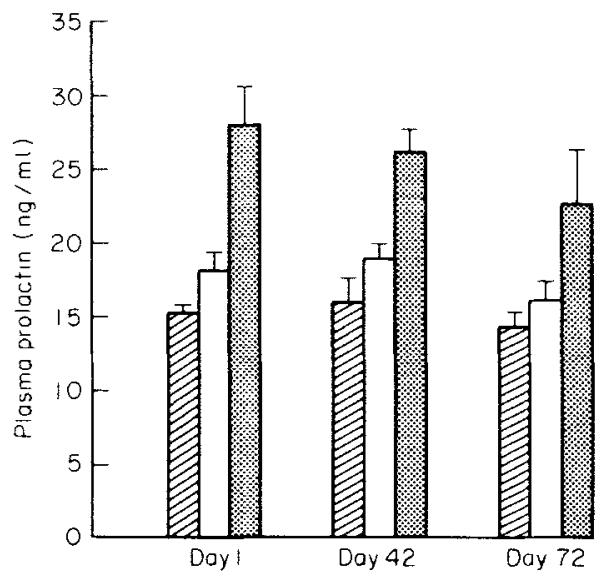

Fig. 2. Mean day time ( $(a)$, night-time ( $\square$ ), and peak ( $(\mathrm{s})$ nocturnal prolactin concentrations on days $1,42$, and 72 (mean $\pm S E M)$.

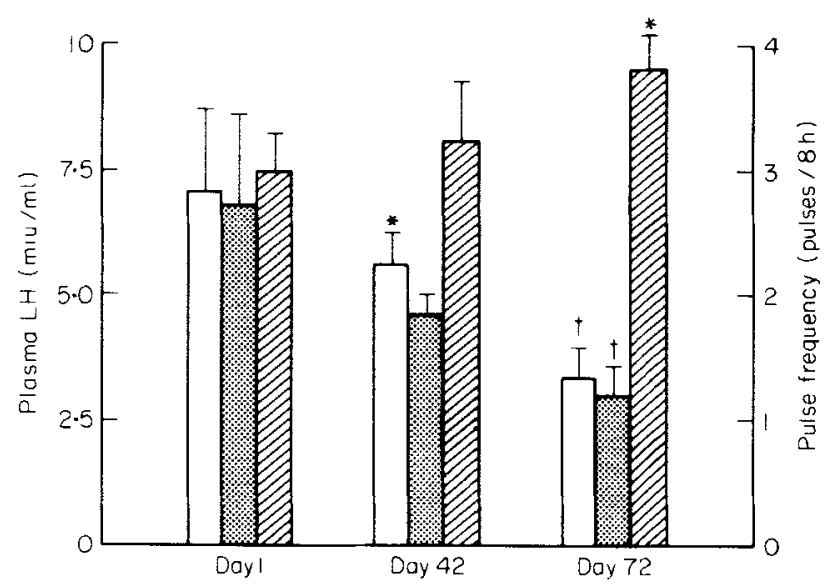

Fig. 3. Mean LH (a), LH pulse amplitude ( $(0)$, and LH pulse frequency ( $($ ) on days 1,42 , and 72 . $($ Mean $\pm \mathrm{SEM})(* P<0.05,+P<0.02)$.

Nocturnal GH secretion was altered by cimetidine therapy and the mean nocturnal GH level was decreased in five of the six men. A $33 \%$ decrease $(P<0.025)$ was present after 6 weeks of cimetidine, which returned to baseline on day 72 (Table 3). Peak nocturnal GH levels were also lower on day 42 compared with day 1 and day 72 , but were not statistically different as in two men peaks were of similar height but shorter duration. Nocturnal GH levels in one man before, during and after cimetidine are shown in Fig. 1.

\section{Prolactin secretion}

Plasma prolactin concentrations during the day and night are shown in Fig. 2. The mean day-time and nocturnal prolactin levels, and time and magnitude of peak nocturnal prolactin levels were not different before (day 1), during (day 42), or after (day 72) cimetidine therapy. Basal prolactin and peak responses to insulin and TRH on days 1 and 42 were not altered by cimetidine (Table 1 ). 


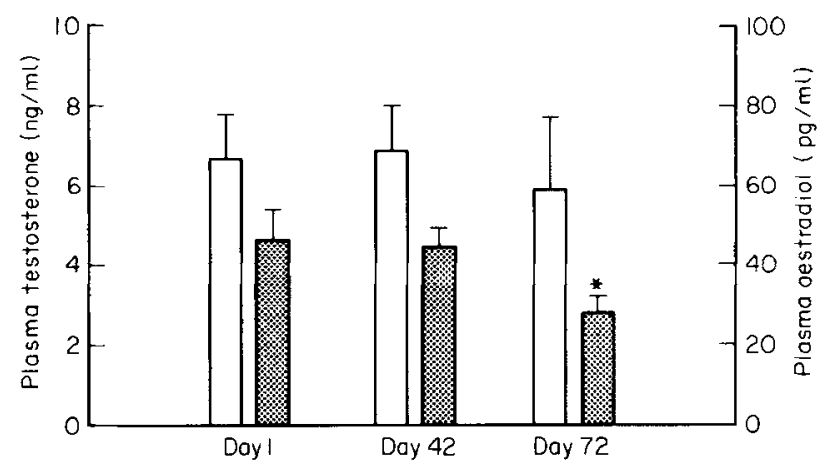

Fig. 4. Plasma testosterone ( $\square$ ), and oestradiol (a) concentrations on days 1, 42, and 72. $\left(\right.$ Mean \pm SEM) $\left({ }^{*} P<0.025\right)($ Conversion to SI units: testosterone $\times 3.5$ to $\mathrm{nmol} / 1$, oestradiol $\times 3.7$ to $\mathrm{pmol} / 1$ ).

\section{Gonadotrophins and gonadal steroids}

Plasma LH concentrations are shown in Fig. 3. Mean plasma LH declined by $20 \%$ on day 42 of cimetidine treatment $(P<0.05)$ and was $55 \%$ lower on day $72(P<0.02)$. The frequency of spontaneous LH pulses was similar on days 1 and 42 , but was increased on day $72(P<0.05)$. Concomitantly, LH pulse amplitude decreased slightly by day 42 but was not significantly lower than day 1 levels until day $72(P<0 \cdot 02)$. All four men studied on day 72 showed these changes. Furthermore, maximum LH responses to GnRH in the six men were decreased on day 42 compared with day $1(P<0 \cdot 02)$ (Table 1$)$.

Mean plasma FSH concentrations $(2 \cdot 3 \pm 0 \cdot 2 \mathrm{miu} / \mathrm{ml}$ on days 1 and 42$)$ and FSH responsiveness to GnRH were unaffected by 6 weeks of cimetidine treatment (Table 1).

Plasma testosterone and oestradiol concentrations are noted in Fig. 4. Plasma testosterone was not different before, during, or after cimetidine therapy. Plasma oestradiol concentrations remained unchanged on days 1 and 42 , but were $38 \%$ lower $(P<0.025) 1$ month after discontinuation of cimetidine. This delayed fall in oestradiol occurred in all four men studied on day 72 .

\section{DISCUSSION}

Conflicting reports of altered hormone secretion have been noted in patients taking cimetidine (Hall 1976; Dellefave et al., 1977; Bonnet et al., 1978; Delitalia et al., 1979; Van Thiel et al., 1979; White et al., 1979). Some of the differences observed may have resulted from the use of infrequent sampling schedules and thus we have used frequent sampling for prolonged periods to improve accuracy (Santen \& Bardin, 1973), and also to examine possible changes in the biological rhythms of hormone secretion.

Prolactin has been a primary candidate as the cause of impotence and gynaecomastia in men taking cimetidine (Dellefave et al., 1977; Wolfe, 1979; Bonnet et al., 1978). Many investigators found a transient effect of i.v. cimetidine on plasma prolactin (Delitala $e t$ al., 1979; Daubresse et al., 1979; Carlson \& Ippoliti, 1977), but the effect of oral cimetidine on prolactin secretion is debatable (Hall, 1976; Dellefave et al., 1977; Bonnet et al., 1978). In the present study, oral cimetidine produced no changes in basal or stimulated plasma prolactin concentrations. The difference between the effects of oral and intravenous cimetidine on prolactin may relate to the differences in plasma cimetidine concentrations. 
A threshold of prolactin release is seen after an intravenous bolus of $200 \mathrm{mg}$ of cimetidine (Delitala et al., 1979). An i.v. injection of $100 \mathrm{mg}$ produces peak cimetidine levels 4 - to 5 -fold higher than seen in this study, and thus oral cimetidine in doses required for ulcer disease would be unlikely to affect prolactin levels. Many of the original reports referred to gynaecomastia in patients with the Zollinger-Ellison syndrome (DelleFave et al., 1977) which is treated with larger doses of cimetidine (McCarthy, 1978). In these circumstances the higher plasma cimetidine levels could have caused increased prolactin secretion.

Nocturnal growth hormone secretion was reduced by cimetidine and while documentation of sleep stage by electroencephalography was not performed, indirect evidence suggests that sleep was not affected. First, prolactin is also secreted in a sleep-related manner (Weitzman et al., 1975; Nokin et al., 1972), and the lack of any changes in the nocturnal prolactin rise suggests that sleep patterns were not altered. Secondly, the decline in nocturnal $\mathrm{GH}$ reversed after stopping cimetidine suggesting that this is a transient effect of cimetidine therapy. However, further investigation with electroencephalographic monitoring would be needed to accurately delineate any effects of cimetidine on the patterns of sleep.

Our data suggest that a $\mathrm{H}_{2}$ histamine receptor may be involved in control of nocturnal $\mathrm{GH}$ secretion. Previous studies have shown histamine to be present in the brain with high concentrations in the median eminence (Taylor et al., 1972; Brownstein et al., 1974). Both $\mathrm{H}_{1}$ and $\mathrm{H}_{2}$ histamine receptors are present in that area (Brimble \& Wallis, 1973; Baudry et al., 1975) and $H_{1}$ antihistamines have been shown to inhibit arginine induced $\mathrm{GH}$ secretion (Pontiroli et al., 1976). The significance of the changes in growth hormone secretion remain unknown. However, the prolonged use of an oral dose of cimetidine at bedtime to decrease nocturnal gastric acid secretion (Gray et al., 1978) should be undertaken with caution in growing children and adolescents.

Urinary free cortisol excretion was decreased markedly by cimetidine treatment. The mechanism by which this occurs is uncertain but an alteration in adrenal cortisol production seems unlikely as the diurnal cortisol rhythm and cortisol responses to insulin hypoglycemia were not changed. Two other possibilities may be involved. First, cimetidine alters warfarin-induced anticoagulation (Flind, 1978), presumably by altering binding to plasma proteins. Altered cortisol binding to binding globulins could alter the rate of free cortisol clearance. A second mechanism may involve alteration of cortisol metabolism or clearance by the kidney itself. The reduced creatinine clearance, an effect noted by others (McElligott, 1978; Kruss \& Littman, 1978) may be evidence of this. However, correcting the excretion of free cortisol for the reduced glomerular filtration does not fully explain the reduced cortisol excretion. Recent evidence has shown that histamine receptors are present in both the glomerulus and tubule and are blocked by $\mathrm{H}_{2}$ but not $\mathrm{H}_{1}$ antagonists (Torres et al., 1978). As cortisol is filtered by the glomerulus and then reabsorbed in the tubule (Beisel et al., 1964) cimetidine could directly reduce cortisol excretion by effects at either site. A tubular effect is supported by the fact that calculation of UFC secretion per $100 \mathrm{ml}$ of GFR did not correct the decrease in UFC concentrations. As other urinary steroids may be similarly affected, their measurements should be interpreted with caution in patients on cimetidine therapy.

Interesting findings were noted in the effect of the $\mathrm{H}_{2}$ receptor antagonist on gonadotrophin and gonadal steroid secretion. The mechanisms involved in the gonadotrophin and gonadal steroid changes and the persistence of the changes after therapy has been stopped are unclear. The decline in mean LH concentrations probably results from 
the decrease in LH pulse amplitude which is not fully compensated by the small increase in pulse frequency. This effect would appear to be mediated via hypothalamic $\mathrm{H}_{2}$ receptors as spontaneous LH pulsations probably reflect endogenous GnRH secretion (Root et al., 1972; Yen et al., 1972). As a result of decreased endogenous GnRH secretion, LH stores in the pituitary decrease more rapidly than FSH (Santen \& Ruby, 1979), and less LH is released in response to exogenous GnRH. The decrease in LH pulse amplitude and the decreased $\mathrm{LH}$ responsiveness to $\mathrm{GnRH}$ are similar changes to those noted in men given oestradiol infusions (Santen, 1975). A reduction in oestradiol binding to sex hormone binding globulin (SHBG) induced by cimetidine could produce an increase in free oestradiol which would not be evident when total serum oestradiol is measured. Cimetidine impairs the binding of androgen to its peripheral receptors (Winters et al., 1979; Funder \& Mercer, 1979) and this could also result in an increase in the effective oestradiol to testosterone $(\mathrm{E} / \mathrm{T})$ ratio. Such changes could explain the alterations in gonadotrophin secretion as well as the reported increased incidence of gynaecomastia after cimetidine, but further investigation is necessary to clarify these effects.

In conclusion, $\mathrm{H}_{2}$ receptors appear to be involved in the control of rhythms of hormonal secretion. The exact mechanisms of the effects on $\mathrm{LH}$ and oestradiol as well as changes in GH and UFC remains to be elucidated. However, the alterations should be taken into account in the interpretation of hormone measurements in patients receiving cimetidine therapy.

\section{ACKNOWLEDGEMENTS}

This is to acknowledge the nursing staff of the Clinical Research Center for their excellent technical assistance, Dr P. Stetson for his assay of cimetidine concentrations, and Beth Yeakel for her secretarial assistance. This work was supported by Grant 5MO1 RR -42 from the Division of Research Resources, National Institutes of Health.

\section{REFERENCES}

Baundry, M., Martres, M.P. \& Schartz, J.C. (1975) $\mathrm{H}_{1}$ and $\mathrm{H}_{2}$ receptors in the histamine-induced accumulation of cyclic AMP in guinea pig brain slices. Nature, 253, 362-363.

Beisel, W.R., Diraimondo, U.C. \& Forsham, P.H. (1964) Cortisol transport and disappearance. Annals of Internal Medicine, 60, 641-652.

Bonnet, H.G., Griewe. M., Hander, J.P. Afagona, C. \& SChneider, H.P.G. (1978) Effects of cimetidine on prolactin, LH, and sex steroid secretion in male and female volunteers. Acta Endocrinologica, 88, 428-440.

Brimble, M.H. \& Wallis, D.I. (1973) Histamine $\mathrm{H}_{1}$ and $\mathrm{H}_{2}$ receptors at a ganglionic synapse. Nature, 246, 156-158.

Brownstein, M.J., SaAdeura, J.M., Pakovits, M. \& Axelrod, J. (1974) Histamine content of hypothalamic nuclei of the rat. Brain Research, 77, 151-156.

CARlson, H.E. \& IPPOLITI, A.F. (1977) Cimetidine, an $\mathrm{H}_{2}$ antihistaminic stimulates prolactin secretion in man. Journal of Clinical Endocrinology, 45, 367-370.

Dash, R.J., England, B.G., Midgley, A.R. \& Niswender, G.D. (1975) A specific nonchromatographic radioimmunoassay for human plasma cortisol. Steroids, 26, 647-661.

Daubresse. J.C., Meunior, J.C. \& Ligny, G. (1978) Plasma protein and cimetidine. Lancet, i, 99.

Delitala, G.. Stubbs, W.A.. Wass, J.A.H., Jones, A., Williams, S. \& Besser, G.M. (1979) Effects of the $\mathrm{H}_{2}$ receptor antagonist on pituitary hormones in man. Clinical Endocrinology, 11, 161-167.

Deleefave, G.H., Tambussano, G., Demagistris, L., Natoli, C., Santoro, M.L., Carratu, R. \& Torsoli, A. (1977) Gynecomastia with cimetidine. Lancet, i, 1319.

England, B.G., Niswendeb, G.D., \& MidGLeY, A.R. (1974) Radioimmunoassay of estradiol $17-\beta$ without chromatography. Journal of Clinical Endocrinology, 38, 42-50. 
Flind, A.C. (1978) Cimetidine and oral anticoagulants. Lancet, ii, 2054.

FortulN, N.J. \& Weiss, J.L. (1977) Exercise stress testing. Circulation, 56, 699-712.

Funder. J.W. \& Mercer, J.E. (1979) Cimetidine, a histamine $\mathrm{H}_{2}$ receptor antagonist, occupies androgen receptors. Journal of Clinical Endocrinology, 48, 189-196.

Gray, G.R., Smith, I.S., Mackenzie. I. \& Gillespie, G. (1978) Long term cimetidine in the management of severe duodenal ulcer dyspepsia. Gastroenterologi. 74, 397-401.

GRIFFITHS, R., LEE, R.M. \& TAYLOR, D.C. (1977) Kinetics of cimetidine in man and experimental animals. In Proceedings of the Second International Symposium on Histamine H2-Receptor Antagonists, pp. 38-43. Excerpta Medica, Amsterdam.

HaLL, W.H. (1976) Breast changes in males on cimetidine. New England Journal of Medicine, $295,841$.

Harsoulis, P. Marshall, J.C., Kuku. S.F., Burke, C.W., London, D.R. \& Fraser. T.R. (1973) Combined test for assessment of anterior pituitary function. British Medical Journal, iv, 326-329.

HeN, , R.M.. ISENBerg, J.I., Maxwell, V. \& SturdeVant, R.A.L. (1975) Inhibition of gastric acid secretion by cimetidine in patients with duodenal ulcer. New England Journal of Medicine, 293, 371-375.

Kruss. D.M. \& Littmax, A. (1978) Safety of cimetidine. Gastroenterologv, 74, 478-483.

LABrooy. S.H., Misiewitz, J.J. \& DelitalA, G. (1978) Studies on the effect of cimetidine on anterior pituitary hormones: are they clinically relevant? Proceedings of the British Society of Gastroenterology, Edinburgh, September 20-23, Abstract S3.

MCCARTHY, D.M. (1978) Report on the United States experience with cimetidine in Zollinger-Ellison Syndrome and other hypersecretory states. Gastroenterology, 74, 453-458.

MCELLIGOTT. M. (1978) Impaired creatinine clearance after cimetidine. Lancet, $\mathbf{i}, 99$.

Midgley, A.R. (1966) Radioimmunoassay: a method for human chorionic gonadotrophin and human luteinizing hormone. Endocrinolog., 79, 10-18.

MidGLEY, A.R. (1967) Radioimmunoassay for follicle-stimulating hormone. Journal of Clinical Endocrinology, 27, 295-299

Nokin, J., Vekemans, M.. LHermite, M. \& RoByn, C. (1972) Circadian periodicity of serum prolactin concentration in man. British Medical Journal, iii, 561-562.

Payne, A.H.. Kelch, R.P.. Murono, E.P. \& Kerlan, J.T. (1977) Hypothalamic, pituitary, and testicular function during sexual maturation of the male rat. Journal of Endocrinology, 72, 17-26.

Pekary, A.. Hershman. J.M. \& Parlow. A.F. (1977) A sensitive and precise radioimmunoassay for human thyroid-stimulating hormone. Journal of Clinical Endocrinology, 41, 476-484.

Pontiroli, A.E., Viberti, G., Vicari, A. \& Pozza, G. (1976) Effect of antihistaminic agents meclastine and dexchlorpheniramine on the response of human growth hormone to arginine infusion and insulin hypoglycemia. Journal of Clinical Endocrinology. 43, 582-586.

Root, A.. Oecherney. D., Reiss. D., Duchett, G., Garcia, C. \& Wallach, E. (1972) Episodic secretion of luteinizing and rollicle stimulating hormones in agonadal and hypogonadal adolescents and adults. Joumal of Clinical Endocrinolog. 35, 700-708.

SANTEN. R.J. (1975) Is aromatization of testosterone to estradiol required for inhibition of luteinizing hormone secretion in men. Journal of Clinical Investigation, 56, 1555-1570.

Santen. R.J. \& Bardin. C.W. (1973) Episodic luteinizing hormone secretion in man. Journal of Clinical Intestigation, 52, 2617-2628.

SANTEN. R.J. \& RUBY. E.B. (1979) Enhanced frequency and magnitude of episodic luteinizing hormone-releasing hormone discharge as a hypothalamic mechanism for increased luteinizing hormone secretions. Journal of Clinical Endocrinolog.', 48, 395-404.

SCHALCH, D.S. \& PARKFr. M.L. (1964) A sensitive double antibody immunoassay for human growth hormone in plasma. Nature, 203, 1141-1142.

Sinha, Y.N.. Selby, F.W., Lewis, U.J. \& VANderlaAN, W.P. (1973) A homologous radioimmunoassay for human prolactin. Journal of Clinical Endocrinology. 36, 509-516.

TAYLOR, K.M., GFELLER, F. \& SNyder, H. (1972) Regional localization of histamine and histadine in the brain of the rhesus monkey, Brain Research, 4, 171-179.

Torres, V.E., Northrup. T.E., Eowardos, R.M., Shah, D.V. \& Dousa, T.P. (1978) Modulation of cyclic nucleotides in isolated rat glomeruli. Journal of Clinical Intestigation, 62, 1334-1343.

Valk, T.W., England, B.G. \& Marshall, J.C. (1979) Pituitary function on oral cimetidine. Clinical Research, 27, 681A.

Van Thiel, D.H., Gavaler, J.S., Smith, W.I., JR. \& Paul, G. (1979) Hypothalamic-pituitary-gonadal dysfunction in men using cimetidine. New England Journal of Medicine, 300, 1012-1015. 
WeITZMaN, E.D., BoyaR, R.M., KAPEN, S. \& HellmaN, L. (1975) The relationship of sleep and sleep stages to neuroendocrine secretion and biological rhythms in man. Recent Progress in Hormone Research, 31, $399-446$.

WhITE, M.C., GoRE, M. \& JewELl, D.P. (1979) Endocrine function after cimetidine. New England Journal of Medicine, 301, 502.

WINSHIP, D.H. (1978) Cimetidine in the treatment of duodenal ulcer; review and commentary. Gastroenterology, 74, 402-406.

WINTERS, S.J., BANKS, J.L. \& LoRIAUX, D.L. (1979) Cimetidine is an anti-androgen in the rat. Gastroenterology, 76, 504-508.

WOLFE, M.M. (1979) Impotence on cimetidine treatment. New England Journal of Medicine, 300, 94.

YeN, S.S.C., TSAI, C.C., VANDENBERG, G. \& REBar, R. (1972) Gonadotropin dynamics in patients with gonadal dysgenesis: a model for the study of gonadotropin regulation. Journal of Clinical Endocrinology, 35, 897-906. 